\title{
Assessing Criteria That Matter To Students' Satisfaction In Private Higher EDUCATION
}

\author{
Rasha Abd El Aziz, Hend Abd El Halim \\ Business Information Systems Department, College of Management and Technology, \\ Arab Academy for Science and Technology and Maritime Transport, Alexandria, Egypt.
}

\begin{abstract}
Egypt is one of the major countries in the region, especially with its high population. The large number of students per class and the shrinking budgets has highlighted the role of private sector universities; as it can serve a great number of students while maintaining the low number of students per class due. Although literature is rich with studies regarding higher education (HE) universities, key criteria to students'satisfaction in the Egyptian context; especially in private HEstill need to be investigated in order to assess their impact on students' overall satisfaction.

Accordingly, the research inquires on the main criteria that affect students' overall satisfaction with regards to the staff value, educational e-services and knowledge at a college in a private university in Egypt; as it offers a variety of e-educational services, which makes it a suitable vehicle for the study at hand. The surveyed college, has 1701 enrolled students, where 200 structured questionnaires were randomly distributed over students, with 103 questionnaires returned and considered valid. Data was statistically analysed and hypotheses were tested using chi-square, correlation, and regression tests.

Finally, the research findings confirm a positive relation between staff, educational e-services, and knowledge values together with students' satisfaction. Hen conclusions were drawn and, recommendations were made to decision makers highlighting the importance of these criteria in particular, and the need to be given more attention.
\end{abstract}

\section{KEYWORD}

Educational e-services; students' satisfaction, private universities, higher education

\section{INTRODUCTION}

The ways services are delivered to customers have changed, and automated applications were noticeable due to the penetration of technology and computers in many different sectors including education [1].The environment of $\mathrm{HE}$ is developing due to a number of criteria such as rising costs, crowded classrooms and shrinking budgets has highlighted the need for providing satisfactory educational services to HE students [2].

Egypt in particular has a great potential to expand in e-learning activities due to its high population, which exceeds 84 million [3]. The Egyptian HE sector includes 17 public universities 
International Journal of Advanced Information Technology (IJAIT) Vol. 8, No.4/5, October 2018

with 14, 31,469 enrolled students and 19 private universities, with 71,715 enrolled students located in major cities [4]. It was noticed that parents choose private higher education in an attempt to avoid HE problems associated with the public sector [2].

Therefore, the main subject of the research paper is to assess the impact of staff, educational eservices, and knowledge values on students' satisfaction. This calls for the following research question:

- What are the main criteria that affect students' satisfaction with regards to the values provided in Egyptian private universities?

\section{LiteratURE REVIEW}

The level of satisfaction had got considerable attentions in public as well as in private sector [5]. Learning institutions in Egypt have recognised the significance of investing in technology in order to address criteria such as controlling costs, attracting students and fulfilling customers' needs like most service providers worldwide [6].

Therefore, in order to promote e-learning in Egypt, it is required to understand the main criteria that affect students' overall satisfaction [2].Literature has investigated the main criteria required for customer satisfaction in terms of various emotions, behaviors, and features of the service experience related to satisfaction. However, the majority of studies were conducted in the West, with few conducted in developing countries[7] [8].

In 2017, a study conducted in Ethiopoa [9] revealed that although the majority of undergraduate students are satisfied with the service offered by the university, yet the number of dissatisfied students were not insignificant. The key factors to satisfaction was found to be the gender, studentstaff interaction, student support, and facility supervision. In the same year, an investigation was conducted to measure students' satisfaction with educational services delivered by the two countries' universities. The study recommended that Iraqi universities should give more role to students' satisfaction in order to improve students' satisfaction level [10]. Students' satisfaction has also been proven as an important aspect in the research conducted in Croatia, where the relationship between satisfaction and behavioural intentions of students was examined. A significant direct and positive relationship was proven making it useful for decision makers to attract, educate, and retain STEM (science, technology, engineering, and mathematics) and IC (information-communication) students.

A study in USA found that faculty, academic staff, and classes are the main criteria that affect students' satisfaction [11]. Another study also conducted in USA revealed that there are significant relationships between service performance and student satisfaction that will aid institutions to predict and measure student satisfaction and retention [12].In Pakistan, a study revealed that teachers' expertise, courses offered, learning environment and classroom facilities are the main criteria that affect the student satisfaction with the quality of education offered by different private and public sector universities [13]. A study conducted in Athens, Greece identified five different criteria as the criteria for students' satisfaction; namely program study, academic staff, equipment, administrative services, and image [14]. 
International Journal of Advanced Information Technology (IJAIT) Vol. 8, No.4/5, October 2018

A master thesis conducted in Sweden found that students were satisfied with the university, despite a negative service quality-gap. It also found that service quality only affected customer satisfaction to a small degree, but found a positive relation between the impact of positive news and the level of satisfaction amongst the students [15]. In Indonesia, a study proved that some factors must be prioritized such as the ability to respond effectively to solve the problems, fairness in providing assistance and attention of the government to higher education [16]. On the other hand, an investigation conducted in India, showed that only four of factors (collective learning, satisfaction, collaborative communication, and time) are considered important to students [17].

\section{ReSEARCh Methodology}

Based on the literature review that proves that private universities have a potential to satisfy students [18]; especially in countries with high population such as Egypt [1] [19] [20], this paper testswhether students are satisfied with the current educational services provided at one of the major private universities in Egypt [4].

The population of interest for this study is the private higher education students studying Business Administration, regardless of their major, in Alexandria, Egypt. Alexandria is the second-largest city and is the country's largest seaport in Egypt, in terms of importance and population size [19]. The surveyed college, namely the College of Management and Technology, has 1701 enrolled students. The sampling technique used is simple random sampling. Based on confidence level $95 \%$ and confidence interval \pm 10 , the sample size calculated is 91 students [20].

A structured questionnaire was designed and distributed over 200 student respondents. Data collected was statistically analysed using SPSS, chi-square, correlation, and regression tests were conducted.In order to investigate the research framework, a set of hypotheses have been devised as shown below:

H1There is no significant difference between staff value and students' overall satisfaction.

H2 There is no significant difference between educational e-services value and students' overall satisfaction.

H3There is no significant difference between knowledge and skills value and students' overall satisfaction.

\section{Data Collection}

Questionnaires were designed in English and translated into Arabic. The translation of the questionnaire form was conducted by a certified translation office in Egypt in order to ensure the validity of the translated version of the instrument used. Questionnaire forms were distributed in both languages, according to respondents' preferences. The questionnaire included four variables distributed among 15 Likert scale questions, where a response of 1 means 'totally agree', a response of 2 means 'agree', 3 means 'neutral', 4 means 'disagree', and a response of 5 means 'totally disagree'. 200 questionnaire forms were randomly distributed over HE students at the surveyed university. A total of 103 valid questionnaires were returned. A summary of the questionnaire form and variables relationships presented in Table 1. 
International Journal of Advanced Information Technology (IJAIT) Vol. 8, No.4/5, October 2018

Table 1 Questionnaire and varibles relationships summary

\begin{tabular}{|c|c|c|c|c|c|}
\hline 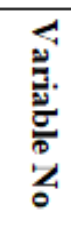 & Statement & 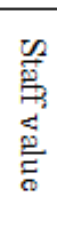 & 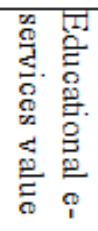 & 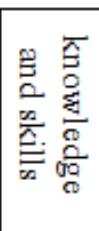 & 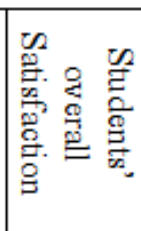 \\
\hline 1 & The service at my department is satisfactory & & & & $\sqrt{ }$ \\
\hline 2 & The service is convenient compared to my expectations & & & & $\sqrt{ }$ \\
\hline 3 & $\begin{array}{l}\text { I have gained knowledge and skills throughout the course of } \\
\text { study }\end{array}$ & & & $\sqrt{ }$ & \\
\hline 4 & The senior staff members are generally helpful & $\sqrt{ }$ & & & \\
\hline 5 & The junior staff members are generally helpful & $\sqrt{ }$ & & & \\
\hline 6 & Staff members are knowledgeable and skillful & $\sqrt{ }$ & & & \\
\hline 7 & Studying at my program is exciting and enjoyable & & & $\sqrt{ }$ & \\
\hline 8 & The educational e-services received are useful & & $\sqrt{ }$ & & \\
\hline 9 & The educational e-services received are easy to use & & $\sqrt{ }$ & & \\
\hline 10 & The educational e-services received are responsive & & $\sqrt{ }$ & & \\
\hline 11 & The educational e-services received are satisfactory & & $\sqrt{ }$ & & \\
\hline 12 & I have made the right choice by joining this department & & & & $\sqrt{ }$ \\
\hline 13 & I would encourage potential students to join the academy & & & & \\
\hline 14 & I would encourage potential students to join my department & & & $\sqrt{ }$ & \\
\hline 15 & My department has prepared me to the job market & & & $\sqrt{ }$ & \\
\hline
\end{tabular}

\section{Data Analysis}

As illustrated in Table 1, the questionnaire contained 15statementsinvestigating students' view of staff value, educational e-services value, knowledge and skills value, and students' overall satisfaction.In order to analyze the questionnaire data, statistical analysis was done using the Statistical Package for Social Science (SPSS) software. Frequencies were used to describe the results. Reliability Analysis - Cronbach Alpha was conducted in order toensure the reliabilityof the study variables. Chi-square, correlation, and regression tests were used to illustrate the existence of association between variables.

\subsection{DESCRIPTIVE ANALYSIS - FREQUENCIES}

- Most of the surveyed students (79.6\%) are satisfied with $13.6 \%$ neutral and only $6.8 \%$ dissatisfied.

- $63 \%$ of investigated feel that the received service is convenient to their expectations. $26.2 \%$ are not able to decide, while $10.7 \%$ feel that the received service is not convenient.

- The gained knowledge and skills is satisfying for $68.9 \%$ of the surveyed students. The neutral view studentsreached $23 \%$ of the investigated students. The not satisfied students are $7.8 \%$ of the investigated students.

- The gained knowledge and skills is satisfying for $68.9 \%$ of the surveyed students. The neutral view studentsreached $23 \%$ of the investigated students. The not satisfied students are $7.8 \%$ of the investigated students. 
International Journal of Advanced Information Technology (IJAIT) Vol. 8, No.4/5, October 2018

- Staff members are knowledgeable and skilled based on $70.6 \%$ of the investigated students. $21.6 \%$ of the investigated students have a neutral view toward the same issue. Based on $7.9 \%$ of the investigated students' staff are not knowledgeable and skilled.

- Program is exciting and enjoyable: $61.8 \%$ of the investigated students agreed that the program is exciting and enjoyable. The students with a neutral view perform $25.5 \%$. The program is not exciting and not enjoyable based on $12.8 \%$ of the investigated students.

- E-services are(useful, easy to use, andresponsive): $65 \%, 66 \%$,and $62.7 \%$ of the investigated students decided that e-services are useful, easy to use, andresponsive with respect to the order. The students with contradicting view reached $7.8 \%, 8.7 \%$, and $7.8 \%$, respectively. Neutral view students' perform $27.2 \%, 25.2 \%$, and $29.4 \%$ in sequence.

- $71.8 \%$ of the surveyed students would encourage potential students to join the academy. The neutral view extended to $15.5 \%$, and $12.7 \%$ would not encourage potential students to join the academy.

- $60.2 \%$ of the surveyedstudents would encourage potential students to join the same department, $24.3 \%$ are neutral, and $15.5 \%$ would not. $50.5 \%$ of the investigatedstudent agreed that their departments prepared them to the job market, $33 \%$ have a neutral view, while $16.5 \%$ decided that their departments have not prepared them to the job market.

- $73 \%$ of the investigated students believe that senior staff is helpful, $72.8 \%$ believe the same regarding junior staff. On contrast, senior staff are regarded as not helpful based on $9.7 \%$ of the investigated students, and junior staff are seen not helpful according to $7.7 \%$. The students who have a neutral view toward senior and junior staffs were $16.5 \%$ and $19.4 \%$ respectively.

- $69.3 \%$ believe that e-services are satisfactory, while $6.9 \%$ do not, leaving $23.8 \%$ neutral. $35 \%$ think that they have made the right choice by joining this department, $24 \%$ are neutral and only $11.7 \%$ think that they not taken the right choice by joining this department.

- $68.9 \%$ agree that they gained knowledge and skills, $23.3 \%$ are neutral, and only $7.8 \%$ disagree.

- $61.8 \%$ believe that the program is exciting and enjoyable, $12.7 \%$ believe it is not, and $25.5 \%$ has a neutral view toward their studying program

- Over half of the investigated students (50.5\%)agree that their department has prepared them to the job market, $33 \%$ has a neutral view of point, and $16.5 \%$ disagree.

\subsection{HYPOTHESIS TESTING}

The Cronbach's alpha is computed for testing reliability, where the value is 0.925 , which exceeds 0.8 ; which is an acceptable level for reliability and illustrates a highly consistent and uniform study measures.In order to understand and determine the main criteria that affect the students' satisfaction, a number of hypotheses were devised and tested as shown below:

\section{H1 There is no significant difference between staff value and students' overall satisfaction.}

- A significant relation between staff value and students' overall satisfaction is illustrated as shown from the chi-square values below in Table 2 and as illustrated in Table 3, variables 1, 2, and 12 have astrong positive correlation with variables 4,5 , and 6.

- This enables rejecting the null hypothesis, and amplifies the importance of understanding the impact of staff value on the students' overall satisfaction. 
International Journal of Advanced Information Technology (IJAIT) Vol. 8, No.4/5, October 2018

Table 2 Chi-Square - Staff value and Students' satisfaction

\begin{tabular}{|c|c|c|c|c|c|}
\hline & Statement & $\begin{array}{l}\text { N of } \\
\text { Valid } \\
\text { Cases }\end{array}$ & $\begin{array}{c}\text { Pearson } \\
\text { Chi-Square } \\
\text { Value }\end{array}$ & $\mathrm{df}$ & $\begin{array}{l}\text { Asymp. } \\
\text { Sig. (2- } \\
\text { sided) }\end{array}$ \\
\hline \multirow{3}{*}{$\begin{array}{l}\text { The service at } \\
\text { my department } \\
\text { is satisfactory }\end{array}$} & $\begin{array}{l}\text { The senior staff members are generally } \\
\text { helpful }\end{array}$ & 103 & $59.236 \mathrm{a}$ & 16 & .000 \\
\hline & $\begin{array}{l}\text { The junior staff members are generally } \\
\text { helpful }\end{array}$ & 101 & $33.636 a$ & 16 & .006 \\
\hline & $\begin{array}{l}\text { Staff members are knowledgeable and } \\
\text { skillful }\end{array}$ & 103 & $40.967 \mathrm{a}$ & 16 & .001 \\
\hline \multirow{3}{*}{$\begin{array}{l}\text { The service is } \\
\text { convenient } \\
\text { compared to } \\
\text { my } \\
\text { expectations }\end{array}$} & $\begin{array}{l}\text { The senior staff members are generally } \\
\text { helpful }\end{array}$ & 103 & $1.142 \mathrm{E} 2 \mathrm{a}$ & 16 & .000 \\
\hline & $\begin{array}{l}\text { The junior staff members are generally } \\
\text { helpful }\end{array}$ & 101 & $49.529 a$ & 16 & .000 \\
\hline & $\begin{array}{l}\text { Staff members are knowledgeable and } \\
\text { skillful }\end{array}$ & 103 & $38.083 a$ & 16 & .001 \\
\hline \multirow{3}{*}{$\begin{array}{l}\text { Ihave made } \\
\text { the right choice } \\
\text { by joining this } \\
\text { department }\end{array}$} & $\begin{array}{l}\text { The senior staff members are generally } \\
\text { helpful }\end{array}$ & 102 & $34.332 \mathrm{a}$ & 16 & .005 \\
\hline & $\begin{array}{l}\text { The junior staff members are generally } \\
\text { helpful }\end{array}$ & 101 & $33.797 a$ & 16 & .006 \\
\hline & $\begin{array}{l}\text { Staff members are knowledgeable and } \\
\text { skillful }\end{array}$ & 102 & $70.802 a$ & 16 & .000 \\
\hline
\end{tabular}

Table 3 Correlations - Staff value and Students' satisfaction

\begin{tabular}{|c|c|c|c|c|c|c|c|}
\hline \multicolumn{8}{|c|}{ Correlations } \\
\hline $\begin{array}{c}\text { variable } \\
\text { No }\end{array}$ & & 1 & 2 & 12 & 4 & 5 & 6 \\
\hline \multirow[t]{2}{*}{1} & Pearson Correlation & 1 & & & & & \\
\hline & Sig. (2-tailed) & & & & & & \\
\hline \multirow[t]{2}{*}{2} & Pearson Correlation & $.511^{* 4}$ & 1 & & & & \\
\hline & Sig. (2-tailed) & .000 & & & & & \\
\hline \multirow[t]{2}{*}{12} & Pearson Correlation & $.484^{* 4}$ & $.574^{* *}$ & 1 & & & \\
\hline & Sig. (2-tailed) & .000 & .000 & & & & \\
\hline \multirow[t]{2}{*}{4} & Pearson Correlation & $.572^{* 4}$ & $.546^{* 4}$ & $.540^{* 4}$ & 1 & & \\
\hline & Sig. (2-tailed) & .000 & .000 & .000 & & & \\
\hline \multirow[t]{2}{*}{5} & Pearson Correlation & $.451^{* *}$ & $.485^{\circ}$ & $.406^{* 4}$ & $.538^{* 4}$ & 1 & \\
\hline & Sig. (2-tailed) & .000 & .000 & .000 & .000 & & \\
\hline \multirow[t]{2}{*}{6} & Pearson Correlation & $.398^{* 4}$ & $.465^{* *}$ & $.346^{4+}$ & $.319^{4 *}$ & $.471^{* 4}$ & 1 \\
\hline & Sig. (2-tailed) & .000 & .000 & .000 & .001 & .000 & \\
\hline
\end{tabular}


International Journal of Advanced Information Technology (IJAIT) Vol. 8, No.4/5, October 2018

Table 4 Model Summary ${ }^{\mathrm{b}}$ - Staff value and Students' satisfaction

\begin{tabular}{|c|c|c|c|c|c|}
\hline Model & $\mathrm{R}$ & R Square & Adjusted R Square & $\begin{array}{l}\text { Std. Error } \\
\text { of the } \\
\text { Estimate }\end{array}$ & Durbin-Watson \\
\hline 1 & $.670^{\mathrm{a}}$ & .449 & .432 & .60328 & 1.869 \\
\hline
\end{tabular}

a. Predictors: (Constant), Variable 6, Variable 5, Variable 4

b. Dependent Variable: Students' overall Satisfaction

Table 5 ANOVA $^{\mathrm{b}}$ - Staff value and Students' satisfaction

\begin{tabular}{|c|c|c|c|c|c|c|}
\hline \multicolumn{2}{|c|}{ Model } & Sum of Squares & $\mathrm{df}$ & Mean Square & $\mathrm{F}$ & Sig. \\
\hline 1 & Regression & 28.775 & 3 & 9.592 & 26.355 & $.000^{3}$ \\
\hline & Residual & 35.302 & 97 & .364 & & \\
\hline & Total & 64.077 & 100 & & & \\
\hline
\end{tabular}

a. Predictors: (Constant), Variable 6, Variable 5, Variable 4

b. Dependent Variable: Students' overall Satisfaction

Table 6 Coefficients $^{\mathrm{a}}$ - Staff value and Students' satisfaction

\begin{tabular}{|c|c|c|c|c|c|c|}
\hline & \multirow[b]{2}{*}{ Model } & \multicolumn{2}{|c|}{ Unstandardized Coefficients } & \multirow{2}{*}{$\begin{array}{c}\begin{array}{c}\text { Standardized } \\
\text { Coefficients }\end{array} \\
\text { Beta }\end{array}$} & \multirow[b]{2}{*}{$\mathrm{t}$} & \multirow[b]{2}{*}{ Sig. } \\
\hline & & B & Std. Error & & & \\
\hline \multirow[t]{4}{*}{1} & (Constant) & .645 & .179 & & 3.598 & .001 \\
\hline & Variable 4 & .254 & .087 & .286 & 2.938 & .004 \\
\hline & Variable 5 & .194 & .074 & .241 & 2.624 & .010 \\
\hline & Variable 6 & .242 & .069 & .306 & 3.528 & .001 \\
\hline
\end{tabular}

a. Dependent Variable: Students' overall Satisfaction

Tables 4, 5, and 6 show the regression analysis results for the research model, where it was found that there is a significant positive impact of variables4, 5 and 6; their P-values are 0.004, 0.010, and 0.001 respectively, ,which are less than 0.05 . Also, the standardized estimates show that the research variables could be ranked according to their importance to students' satisfaction as variable 4 , variable 5 , and variable 6 , as standardized coefficients are $0.286,0.241$, and 0.306 respectively. Therefore, this hypothesis is fully supported, suggesting a significant difference in variable 4, variable 5, and variable 6 with regards to students' satisfaction.In addition, it could be noticed that R-Squared is 0.449 , which means the model explains $45 \%$ of the variation in students' satisfaction through the staff value. 
International Journal of Advanced Information Technology (IJAIT) Vol. 8, No.4/5, October 2018

H2 There is no significant difference between educational e-services value and students' overall satisfaction.

The relation between educational e-services value and students' overall satisfaction is significant as shown from the chi-square values below in Table 7 and as illustrated in Table 8, variables 1, 2, and 12 have a strong positive correlation with variables $8,9,10$, and 14 . These results allow us to reject the null hypothesis, which highlights the impact of educational e-services value on the students' overall satisfaction.

Table 7 Chi-Square -educational e-services value and students' satisfaction

\begin{tabular}{|c|c|c|c|c|c|}
\hline & Statement & $\begin{array}{l}\text { N of } \\
\text { Valid } \\
\text { Cases }\end{array}$ & \begin{tabular}{|l|} 
Pearson \\
Chi-Square \\
Value \\
\end{tabular} & df & \begin{tabular}{|l|} 
Asymp. \\
Sig. (2- \\
sided)
\end{tabular} \\
\hline \multirow{4}{*}{$\begin{array}{ll}\text { The service at my } \\
\text { department } \\
\text { satisfactory }\end{array}$} & The educational e-services received are useful & 103 & $52.036^{\mathrm{a}}$ & 16 & .000 \\
\hline & $\begin{array}{l}\text { The educational e-services received are easy to } \\
\text { use }\end{array}$ & 103 & $65.828^{\mathrm{a}}$ & 16 & .000 \\
\hline & $\begin{array}{l}\text { The educational e-services received are } \\
\text { responsive }\end{array}$ & 103 & $65.971^{\mathrm{a}}$ & 16 & .000 \\
\hline & $\begin{array}{l}\text { I would encourage potential students to join my } \\
\text { department }\end{array}$ & 103 & $31.810^{\mathrm{a}}$ & 16 & .011 \\
\hline \multirow{4}{*}{$\begin{array}{l}\text { The service is } \\
\text { convenient compared } \\
\text { to my expectations }\end{array}$} & The educational e-services received are useful & 103 & $87.785^{\mathrm{a}}$ & 16 & .000 \\
\hline & $\begin{array}{l}\text { The educational e-services received are easy to } \\
\text { use }\end{array}$ & 103 & $72.523^{\mathrm{a}}$ & 16 & .000 \\
\hline & $\begin{array}{l}\text { The educational e-services received are } \\
\text { responsive }\end{array}$ & 103 & $51.223^{\mathrm{a}}$ & 16 & .000 \\
\hline & $\begin{array}{l}\text { I would encourage potential students to join my } \\
\text { department }\end{array}$ & 103 & $65.076^{\mathrm{a}}$ & 16 & .000 \\
\hline \multirow{4}{*}{$\begin{array}{l}\text { I have made the right } \\
\text { choice by joining this } \\
\text { department }\end{array}$} & The educational e-services received are useful & 102 & $64.936^{\mathrm{a}}$ & 16 & .000 \\
\hline & $\begin{array}{l}\text { The educational e-services received are easy to } \\
\text { use }\end{array}$ & 102 & $41.563^{\mathrm{a}}$ & 16 & .000 \\
\hline & $\begin{array}{l}\text { The educational e-services received are } \\
\text { responsive }\end{array}$ & 102 & $54.516^{\mathrm{a}}$ & 16 & .000 \\
\hline & $\begin{array}{l}\text { I would encourage potential students to join my } \\
\text { department }\end{array}$ & 102 & $60.824^{a}$ & 16 & .000 \\
\hline
\end{tabular}


International Journal of Advanced Information Technology (IJAIT) Vol. 8, No.4/5, October 2018

Table 8 Correlations -educational e-services value and students' satisfaction

\begin{tabular}{|c|c|c|c|c|c|c|c|c|}
\hline $\begin{array}{l}\text { Variabl } \\
\text { e No }\end{array}$ & & 1 & 2 & 12 & 8 & 9 & 10 & 14 \\
\hline \multirow[t]{2}{*}{1} & Pearson Correlation & 1 & & & & & & \\
\hline & Sig. (2-tailed) & & .000 & & & & & \\
\hline \multirow[t]{2}{*}{2} & Pearson Correlation & $.511^{* *}$ & 1 & & & & & \\
\hline & Sig. (2-tailed) & .000 & & & & & & \\
\hline \multirow[t]{2}{*}{12} & Pearson Correlation & $.484^{* *}$ & $.574^{* *}$ & 1 & & & & \\
\hline & Sig. (2-tailed) & .000 & .000 & & .001 & & & \\
\hline \multirow[t]{2}{*}{8} & Pearson Correlation & $.357^{* 4}$ & $.368^{* 4}$ & $.321^{* *}$ & 1 & & & \\
\hline & Sig. (2-tailed) & .000 & .000 & .001 & & .000 & & \\
\hline \multirow[t]{2}{*}{9} & Pearson Correlation & $.310^{* 4}$ & $.420^{* *}$ & $.332^{* *}$ & $.641^{* 4}$ & 1 & & \\
\hline & Sig. (2-tailed) & .001 & .000 & .001 & .000 & & .000 & \\
\hline \multirow[t]{2}{*}{10} & Pearson Correlation & $.414^{* *}$ & $.361^{* *}$ & $.403^{* *}$ & $.582^{* *}$ & $.697^{* 4}$ & 1 & $.326^{* 4}$ \\
\hline & Sig. (2-tailed) & .000 & .000 & .000 & .000 & .000 & & .001 \\
\hline \multirow[t]{2}{*}{14} & Pearson Correlation & $.421^{* *}$ & $.564^{* *}$ & $.702^{* *}$ & $.306^{* *}$ & $.385^{* *}$ & $.326^{* *}$ & 1 \\
\hline & Sig. (2-tailed) & .000 & .000 & .000 & .002 & .000 & .001 & \\
\hline
\end{tabular}

Table 9 Model Summary ${ }^{\mathrm{b}}$ - Educational e-services value and Students' satisfaction

\begin{tabular}{|c|c|r|r|r|r|}
\hline Model & $\mathrm{R}$ & R Square & $\begin{array}{c}\text { Adjusted } \mathrm{R} \\
\text { Square }\end{array}$ & $\begin{array}{c}\text { Std. Error of the } \\
\text { Estimate }\end{array}$ & \multicolumn{2}{|c|}{ Durbin-Watson } \\
\hline 1 & $.776^{\mathrm{3}}$ & .603 & .586 & .51316 & 2.083 \\
\hline
\end{tabular}

a. Predictors: (Constant), Variable 11, Variable.9, Variable 10, Variable 8

b. Dependent Variable: Students' overall Satisfaction

Table 10 ANOVA ${ }^{\mathrm{b}}$ - Educational e-services value and Students' satisfaction

\begin{tabular}{|c|c|c|c|c|c|c|}
\hline \multicolumn{2}{|r|}{ Model } & Sum of Squares & $\mathrm{df}$ & Mean Square & $\mathrm{F}$ & Sig. \\
\hline 1 & Regression & 38.737 & 4 & 9.684 & 36.776 & $.000^{3}$ \\
\hline & Residual & 25.543 & 97 & .263 & & \\
\hline & Total & 64.280 & 101 & & & \\
\hline
\end{tabular}

a. Predictors: (Constant), Variable 11, Variable.9, Variable 10, Variable 8

b. Dependent Variable: Students' overall Satisfaction 
International Journal of Advanced Information Technology (IJAIT) Vol. 8, No.4/5, October 2018

Table 11 Coeficients - Educational E-services value and students satisfaction

\begin{tabular}{|c|c|c|c|c|c|c|}
\hline & \multirow[b]{2}{*}{ Model } & \multicolumn{2}{|c|}{ Unstandardized Coefficients } & \multirow{2}{*}{$\begin{array}{c}\begin{array}{c}\text { Standardized } \\
\text { Coefficients }\end{array} \\
\text { Beta }\end{array}$} & \multirow[b]{2}{*}{$\mathrm{t}$} & \multirow[b]{2}{*}{ Sig. } \\
\hline & & B & Std. Error & & & \\
\hline \multirow[t]{5}{*}{1} & (Constant) & .508 & .146 & & 3.482 & .001 \\
\hline & Variable 8 & .215 & .070 & .252 & 3.072 & .003 \\
\hline & Variable 9 & .199 & .064 & .268 & 3.117 & .002 \\
\hline & Variable 10 & .206 & .065 & .258 & 3.162 & .002 \\
\hline & Variable 11 & .183 & .060 & .232 & 3.036 & .003 \\
\hline
\end{tabular}

a. Dependent Variable: Students' overall Satisfaction

Tables 9,10, 11 show the regression analysis results for the research model, where it was found that there is a significant positive impact of variables8, 9, 10 and 11; their P-values are 0.003, $0.002,0.002$, and 0.003 respectively, ,which are less than 0.05 . Also, the standardized estimates show that the research variables could be ranked according to their importance to students' satisfaction as variables8, 9, 10, and 11, as standardized coefficients are $0.252,0.268,0.258$, and 0.232 respectively. Therefore, this hypothesis is fully supported, suggesting a significant difference in variables $8,9,10$, and 11 with regards to students' satisfaction. Additionally, it could be noticed that R-Squared is 0.603 , which means the model explains $60 \%$ of the variation in students' satisfaction through educational e-services value.

\section{H3 There is no significant difference between knowledge and skills value and students' overall satisfaction.}

The relation between educational e-services value and students' overall satisfaction is significant as shown from the chi-square values below in Table 12 and as illustrated in Table 13. Variables 1, 2 , and 12 are positively correlated to variable 3 , variable 7, and variable 15 . As a consequence the null hypothesis is rejected. This highlights the importance of the knowledge value as a major factor that affects students' overall satisfaction. 
International Journal of Advanced Information Technology (IJAIT) Vol. 8, No.4/5, October 2018

Table 12 Chi-Square knowledge and skills value and students' overall satisfaction

\begin{tabular}{|l|l|l|l|l|l|}
\hline & Statement & $\begin{array}{l}\text { N of } \\
\text { Valid } \\
\text { Cases }\end{array}$ & $\begin{array}{l}\text { Pearson Chi- } \\
\text { Square Value }\end{array}$ & $\begin{array}{l}\text { Asymp. } \\
\text { Sig. (2- } \\
\text { sided) }\end{array}$ \\
\hline $\begin{array}{l}\text { The service at my } \\
\text { department is } \\
\text { satisfactory }\end{array}$ & $\begin{array}{l}\text { I have gained knowledge and skills } \\
\text { throughout the course of study }\end{array}$ & 102 & $52.729^{\mathrm{a}}$ & 16 & .000 \\
\cline { 2 - 6 } & $\begin{array}{l}\text { Studying at my program is exciting and } \\
\text { enjoyable }\end{array}$ & 102 & $32.109^{\mathrm{a}}$ & 16 & .010 \\
\cline { 2 - 6 } & $\begin{array}{l}\text { My department has prepared me to the job } \\
\text { market }\end{array}$ & 102 & $34.814^{\mathrm{a}}$ & 12 & .001 \\
\hline $\begin{array}{l}\text { The service is } \\
\text { convenient compare } \\
\text { to my expectations }\end{array}$ & $\begin{array}{l}\text { I have gained knowledge and skills } \\
\text { throughout the course of study }\end{array}$ & 102 & $91.507^{\mathrm{a}}$ & 16 & .000 \\
\cline { 2 - 6 } & $\begin{array}{l}\text { Studying at my programis exciting and } \\
\text { enjoyable }\end{array}$ & 102 & $56.566^{\mathrm{a}}$ & 16 & .000 \\
\cline { 2 - 6 } & $\begin{array}{l}\text { My department has prepared me to the job } \\
\text { market }\end{array}$ & 102 & $45.955^{\mathrm{a}}$ & 12 & .000 \\
\hline $\begin{array}{l}\text { Ihave made the right } \\
\text { choice by joining this } \\
\text { department }\end{array}$ & $\begin{array}{l}\text { Ihave gained knowledge and skills } \\
\text { throughout the course of study }\end{array}$ & 101 & $88.657^{\mathrm{a}}$ & 16 & .000 \\
\cline { 2 - 6 } & $\begin{array}{l}\text { Studying at my program is exciting and } \\
\text { enjoyable }\end{array}$ & 101 & $28.010^{\mathrm{a}}$ & 16 & .032 \\
\cline { 2 - 6 } & $\begin{array}{l}\text { My department has prepared me to the job } \\
\text { market }\end{array}$ & 101 & $39.075^{\mathrm{a}}$ & 12 & .000 \\
\hline
\end{tabular}

Table 13 Correlations : knowledge and skills value and students' overall satisfaction

\begin{tabular}{|c|c|c|c|c|c|c|c|}
\hline variable No & & 1 & 2 & 12 & 3 & 7 & 15 \\
\hline \multirow[t]{2}{*}{1} & Pearson Correlation & 1 & & & & & \\
\hline & Sig. (2-tailed) & & & & & & \\
\hline \multirow[t]{2}{*}{2} & Pearson Correlation & $.511^{* *}$ & 1 & & & & \\
\hline & Sig. (2-tailed) & .000 & & & & & \\
\hline \multirow[t]{2}{*}{12} & Pearson Correlation & $.484^{* *}$ & $.574^{* *}$ & 1 & & & \\
\hline & Sig. (2-tailed) & .000 & .000 & & & & \\
\hline \multirow[t]{2}{*}{3} & Pearson Correlation & $.452^{* *}$ & $.627^{* *}$ & $.437^{* 4}$ & 1 & & \\
\hline & Sig. (2-tailed) & .000 & .000 & .000 & & & \\
\hline \multirow[t]{2}{*}{7} & Pearson Correlation & $.379^{* *}$ & $.458^{* *}$ & $.549^{* *}$ & $.362^{* *}$ & 1 & \\
\hline & Sig. (2-tailed) & .000 & .000 & .000 & .000 & & \\
\hline \multirow[t]{2}{*}{15} & Pearson Correlation & $.465^{* *}$ & $-498^{* *}$ & $.509^{* 4}$ & $.486^{* *}$ & $.386^{* 4}$ & 1 \\
\hline & Sig. (2-tailed) & .000 & .000 & .000 & .000 & .000 & \\
\hline
\end{tabular}

Table 14 Model Summary ${ }^{\mathrm{B}}$ - knowledge and skills value and Students' satisfaction

\begin{tabular}{|c|c|r|r|r|r|}
\hline Model & $\mathrm{R}$ & R Square & $\begin{array}{c}\text { Adjusted R } \\
\text { Square }\end{array}$ & $\begin{array}{c}\text { Std. Error of the } \\
\text { Estimate }\end{array}$ & Durbin-Watson \\
\hline 1 & $.733^{\mathrm{a}}$ & .537 & .517 & .55694 & 2.347 \\
\hline
\end{tabular}

a. Predictors: (Constant), Variable 15, Variable.7, Variable 3, Variable 14

b. Dependent Variable: Students' overall Satisfaction 
International Journal of Advanced Information Technology (IJAIT) Vol. 8, No.4/5, October 2018

Table 15 ANOVA $^{\text {B }}$ - knowledge and skills value and Students' satisfaction

\begin{tabular}{|ll|r|r|r|r|r|}
\hline & Model & Sum of Squares & df & $\begin{array}{c}\text { Mean } \\
\text { Square }\end{array}$ & F & Sig. \\
\hline 1 & Regression & 34.129 & 4 & 8.532 & 27.50 & .000 \\
& & 29.467 & 95 & .310 & & \\
& Residual & 63.596 & 99 & & & \\
Total & & & \\
\hline
\end{tabular}

a. Predictors: (Constant), Variables15, Variables7, Variables 3, Variables 14

b. Dependent Variable: Students' overall Satisfaction

Table 16 Coefficients knowledge and skilla value and students satisfaction

\begin{tabular}{|c|c|c|c|c|c|c|}
\hline \multirow{2}{*}{\multicolumn{2}{|c|}{ Model }} & \multicolumn{2}{|c|}{ Unstandardized Coefficients } & \multirow{2}{*}{$\begin{array}{c}\text { Standardized } \\
\text { Coefficients } \\
\text { Beta } \\
\end{array}$} & \multirow[b]{2}{*}{$\mathrm{t}$} & \multirow[b]{2}{*}{ Sig. } \\
\hline & & B & Std. Error & & & \\
\hline \multirow[t]{5}{*}{1} & (Constant) & .413 & .179 & & 2.309 & .023 \\
\hline & Variables 3 & .434 & .076 & .462 & 5.745 & .000 \\
\hline & Variables 7 & .148 & .061 & .189 & 2.424 & .017 \\
\hline & Variables 14 & .128 & .081 & .160 & 1.572 & .119 \\
\hline & Variables 15 & .120 & .090 & .134 & 1.337 & .184 \\
\hline
\end{tabular}

a. Dependent Variable: Students' overall Satisfaction

Tables 14,15, and 16 show the regression analysis results for the research model. P-values for variables $3,7,14$, and 15 are $0.000,0.017,0.119$, and 0.184 respectively, with variables 3 and 7 being less than 0.05 , and thus are proven to have a significant positive impact. The standardized estimates show the research variables $(3,7,14$, and 15) ranking according to their importance to students' satisfaction; where their standardized coefficients are $0.462,0.189,0.160$, and 0.134 respectively. Therefore, this hypothesis is partially supported, suggesting a significant difference in variable 3, and 7 with regards to students' satisfaction. Moreover, it could be noticed that RSquared is 0.537 , which means the model explains $54 \%$ of the variation in students' satisfaction through the knowledge and skillsvalue.

\section{CONCLUSION}

The paper at hand seeks to identify key criteria to students' satisfaction in the digital era; especially in private higher education in order to assess their impact on students' overall satisfaction.Thus, this research is concerned with the assessment of the educational e-services at a representative private university in Egypt. The study outcomes of the research analysis conducted and hypotheses tested using chi-square, correlations, and regression analysisprove significant differences which confirms the positive relation between staff, educational e-services, and knowledge values together with students' satisfaction. 
International Journal of Advanced Information Technology (IJAIT) Vol. 8, No.4/5, October 2018

This in turn supports previous literature [5][6] [7] [8] [9] [10] [11] [12] [13] [14] [15] [16] [17], and shows that these criteria need to be given more attention. Any investment or planned improvement in staff value, educational e-services, and knowledge and skills value is expected to have a positive impact on the overall students'satisfactionlevel. This does not only apply to the three main variables that were tested; but rather to all subset variables (questionnaire items/statements).

Finally, the research investigation provides decision makers in higher education in general, and private universities in particular with a clear guide that enables them to enhance students' overall satisfaction by realizing and paying more attention to criteria that have the highest influence from students' perspective.

\section{REFERENCES}

[1] Abd El Aziz, R. (2012) ATM Usage: A Stakeholder Analysis the Egyptian Context, 14 March 2012, LAP LAMBERT Academic Publishing, ISBN-10: 384840835X, ISBN-13: 978-3848408351

[2] El Gamal, S and Abd El Aziz, R. (2012), 'Improving higher education in Egypt through e-learning programs: HE students and senior academics perspective', Int. J. Innovation in Education, Inderscience, Vol. 1, No. (4), 2012, pp. 335 - 361.

[3] El Gamal, S., and Abd El Aziz, R. (2011), "The Perception of Students' Regarding E-Learning Implementation in Egyptian Universities", The Fifth International Conference on Digital Society, eL\&mL 2011: The Third International Conference on Mobile, Hybrid, and On-line Learning, ICDS 2011, Gosier, Guadeloupe, France, ISBN: 978-1-61208-120-5.

[4] Information and Decision Support Center (2010) Available at: http://www.idsc.gov.eg/ (Accessed: 9 July, 2018).

[5] Daniel, D., Liben, G., and Adugna, A. (2017) Assessment of Students' Satisfaction: A Case Study of Dire Dawa University, Ethiopia- Journal of Education and Practice www.iiste.org ISSN 2222-1735 (Paper) ISSN 2222-288X (Online) Vol.8, No.4, 2017 Available at: https://files.eric.ed.gov/fulltext/EJ1133033.pdf (Accessed: 24 September, 2018).

[6] Hamdi, N. and Abd El Aziz, R. (2016), "Facebook as an Interaction Platform in Higher Education: The Case of an Egyptian Private University", The Sixth International Conference on Social Media Technologies, Communication, and Informatics, SOTICS 2016, ISBN: 978-1-61208-504-3, August 21 - 25, 2016 - Rome, Italy, pp. 4 - 10.

[7] Torres, E. N. and Ronzoni, G. (2018) "The evolution of the customer delight construct: Prior research, current measurement, and directions for future research", International Journal of Contemporary Hospitality Management, Vol. 30 Issue: 1, pp.57-75,

[8] Abd El Aziz, R., Beeson, I., and Hussein, M. I. (2018), "A Soft Systems Methodology Based Analysis of the ATM System in Egypt", International Journal of Computer and Information Technology (ISSN: 2279 - 0764) Vol. 7, No. 4, pp. $176-183$.

[9] Yaseen Saud Al-Dulaimi, Z. (2017) Education, educational services and students' satisfaction comparative study between Romanian and Iraqi universities. Proceedings of the International Conference on Business Excellence. 11. 10.1515/picbe-2017-0052 Available at: https://www.researchgate.net/publication/319342941_Education_educational_services_and_students'

_satisfaction_-_comparative_study_between_Romanian_and_Iraqi_universities (Accessed: 24 September, 2018).

[10] DeShields, O., Kara, A. Kaynak, E. (2005), 'Determinants of business student satisfacion and retention in higher education: applying Herzberg's two-factor theory' International Journal of Educational Management, Vol. 19 No. (2), pp. 128-139.

[11] Archambault, L. (2008), 'Measuring Service Performance, Student Satisfaction and its Impact on Student Retention in Private, Post-Secondary Institutions', EDU-COM 2008 International Conference. Sustainability in Higher Education: Directions for Change. 
International Journal of Advanced Information Technology (IJAIT) Vol. 8, No.4/5, October 2018

[12] Butt, B. Z. (2010). A study examining the students' satisfaction in higher education. Procedia-Social and Behavioral Sciences, Elsevier, Vol. 2, No. (2), pp. 5446-5450.

[13] Dimas, G. A., Goula, A., and Pierrakos, G. (2011), 'Quality Issues in Higher Education: A Multicriteria Framework of Satisfaction Measures', Vol. 2, No. (3), Creative Education, Scientific Research, pp. $305-312$.

[14] Keblawi, A., Johansson, I., and Sevensson (2013), 'Student Satisfaction in a higher education context', Master Thesis, Kristianstad University.

[15] Purwaningsih, D. (2017), Assessing the Effects of Service Quality of Government and Student Satisfaction in Education's Field, Published under licence by IOP Publishing Ltd

IOP Conference Series: Materials Science and Engineering, Vol.180, No.(1). Available at: http://iopscience.iop.org/article/10.1088/1757-899X/180/1/012003/pdf (Accessed: 13 August, 2018).

[16] Chaurasia, S. (2017) 'An empirical investigation on factors affecting perceived learning by training through simulations', Industrial and Commercial Training, Vol. 49, No. (1), pp.22-32.

[17] Abd El Halim, H. and Abd El Aziz, R. (2017), The influence of educational e-services, advising support, available information, and knowledge acquired on customer satisfaction:The Egyptian private higher education- Journal of Business and Retail Management Research (JBRMR), Vol. 11, No, (4), pp 162-176. Academy of Business and Retail Management -ABRM.

[18] Meštrović,D. (2017), 'Service Quality, Students' Satisfaction and Behavioural Intentions in STEM and IC Higher eDucation Institutions', Interdisciplinary Description of Complex Systems, Vol.15, No. (1), pp. 66-77, 2017 Available at: https://hrcak.srce.hr/file/259877 (Accessed: 22 September, 2018).

[19] Kandil. O. and Abd El Aziz, R. (2018), 'Evaluating the Supply Chain information flow in Egyptian SMEs using Six Sigma: A Case Study', International Journal of Lean Six Sigma, Vol. 9, No. (4), Emerald.

[20] Hussien, M., I. and Abd El Aziz, R (2013), 'Investigating E-Banking Service Quality in one of Egypt's Banks: A stakeholder Analysis', The TQM Journal, Emerald, Quality Improvement in East Africa, Vol. 25, No. (5), pp. 557 - 576.

\section{Authors}

Prof. Dr. RashaAbd El Aziz is a Professor and the Head of Business Information Systems Department at the College of Management and Technology, Arab Academy for Science and Technology, Egypt. She has been awarded her PhD in 2009, the University of the West of England, Bristol, UK. She is a SAP Certified Business Associate. Her current teaching is mainly in the Business Information Systems field. She has published extensively (over 60 publications), a book, academic journal articles and conference papers. She has successfully supervised $7 \mathrm{PhD}$ theses in UK \& Egypt, and 12 Master theses. She currently supervises theses both in UK and Egypt. She participates in charity work with a number of social responsibility teaching and research activities. She is a member in the editorial board of IJEF - Inderscience, IBIMA and ABRM. She isalso a reviewer to a number of specialised International conferences and academic journals at well-known publishers, such as Emerald, ElSevier and Inderscience.

Dr. HendAbd El Halim is an Assistant Professor at the Business Information Systems Department, and the Head of Quality Assurance Unit at the College of Management and Technology, Arab Academy for Science, Technology and Maritime Transport, Egypt. In 2013, she was awarded her PhD Degree from Bolton Business School, University of Bolton, UK. Her teaching courses include Management Information Systems, Decision Support Systems, Systems Analysis and Design, Software Engineering, and Information Systems Project Management. Her research interests include E-business strategies, Quality in Higher Education, Project Management, and Software Engineering. She has participated in research-related events and activities; she is a reviewer for academic papers, and is a member of the conference committee at the ABRM-AASTMT 2nd International Academic Conference 2017. She is also active in social responsibility activities. 